\title{
Upaya Peningkatan Pendapatan Usaha Melalui Analisis Riset Pasar Pada UMKM Kota Tegal
}

\author{
Efforts to Increase Business Income Through Market Research Analysis on MSMES in Tegal City
}

\author{
Anita Karunia ${ }^{*}$, Arifia Yasmin ${ }^{1}$, Hikmatul Maulidah ${ }^{1}$, Ririh Sri Harjanti ${ }^{1}$ \\ ${ }^{1}$ Jurusan DIII Akuntansi, Politeknik Harapan Bersama, Tegal \\ * anita.karunia2810@gmail.com
}

\begin{abstract}
ABSTRAK
Riset pasar adalah proses identifikasi, pengumpulan, analisis, diseminasi, serta penggunaan informasi secara sistematik dan obyektif untuk membantu manajemen membuat keputusan yang berhubungan dengan identifikasi dan penyelesaian masalah dalam bidang pemasaran. Berdasarkan hasil penelitian sebelumnya menunjukkan bahwa strategi yang tepat untuk mengembangkan UMKM di Kota Tegal adalah melalui pemanfaatan peluang yang ada dengan melakukan ekspansi pasar, memperbesar pertumbuhan produksi dan mengupayakan kemajuan teknologi secara maksimal. Strategi tersebut dapat dilakukan salah satunya adalah dengan melakukan riset pasar untuk mengetahui pendapat dan kebutuhan konsumen terkait produk yang ditawarkan oleh UMKM di Kota Tegal. Pelaksanaan pengabdian masyarakat ini telah berjalan sesuai dengan jadwal yang telah direncanakan. Dari kegiatan pengabdian masyarakat yang telah dilaksanakan dapat disimpulkan bahwa kegiatan pengabdian masyarakat dapat dikatakan berhasil dan mendapatkan tanggapan positif peserta kegiatan yang merupakan UMKM Kota Tegal. Hal tersebut ditunjukkan dengan semakin berkembangnya pengetahuan, pemahaman dan ketrampilan peserta mengenai riset pasar.
\end{abstract}

Kata kunci — Riset Pasar, UMKM

\begin{abstract}
Market research is the process of identifying, collecting, analyzing, disseminating, and using information in a systematic and objective manner to help management make decisions related to identifying and solving problems in the marketing sector. Based on the results of previous research, it shows that the right strategy for developing small enterprise business in Tegal City is through exploiting existing opportunities by expanding markets, increasing production growth and striving for maximum technological advancement. One of these strategies can be done is by conducting market research to find out the opinions and needs of consumers related to products offered by small enterprise business in Tegal City. The implementation of this community service has gone according to the planned schedule. From the community service activities that have been implemented, it can be concluded that community service activities can be said to be successful and get positive responses from activity participants who are small enterprise business in Tegal City. This is indicated by the development of participants' knowledge, understanding and skills regarding market research.
\end{abstract}

Keywords - Market Research, small enterprise business 


\section{Pendahuluan}

Persaingan di dunia usaha yang cukup ketat menyebabkan para pelaku usaha terus melakukan upaya perbaikan dan inovasi akan produknya. Upaya tersebut dilakukan oleh para pelaku usaha agar tetap menjaga konsistensinya di dunia usaha. Hal tersebut erat kaitannya dengan tujuan utama dari kegiatan usaha adalah mendapatkan pendapatan dengan tingkat laba yang maksimal. Berbagai macam upaya dilakukan oleh para pelaku usaha untuk meningkatkan pendapatannya. Salah satunya adalah dengan melakukan analisis pasar terkait produk yang dihasilkannya.

Riset pasar adalah proses identifikasi, pengumpulan, analisis, diseminasi, serta penggunaan informasi secara sistematik dan obyektif untuk membantu manajemen membuat keputusan yang berhubungan dengan identifikasi dan penyelesaian masalah dalam bidang pemasaran. Riset pasar juga merupakan fungsi yang menghubungkan konsumen, pelanggan, dan publik dengan pemasar melalui informasiinformasi yang digunakan untuk mengidentifikasikan dan mendefinisikan peluang. Riset pasar perlu dilakukan sebelum memulai usaha baru, memperkenalkan produk baru, maupun mempertahankan usaha yang sudah ada. ${ }^{1}$

Berdasarkan pemahaman terkait riset pasar yang dijelaskan sebelumnya, menunjukkan bahwa riset pasar juga perlu dilakukan pada usaha yang sudah berjalan. Dilakukannya riset pasar pada usaha yang sudah berjalan selain dapat membantu para pengusaha dalam mengidentifikasi seberapa besar produknya dapat diterima oleh masyarakat, tapi juga dapat dilakukan perbaikan dan inovasi sesuai dengan kebutuhan pasar. Hal tersebut menunjukkan bahwa pada akhirnya hasil analisis dari riset pasar dapat meningkatkan pendapatan usaha.

Analisis riset pasar juga perlu dilakukan oleh para pelaku usaha khususnya UMKM di Kota Tegal. Survei yang telah dilakukan sebelumnya melalui penelitian menjelaskan permasalahan yang dialami oleh UMKM di Kota Tegal antara lain minimnya modal usaha, peralatan produksi yang sederhana, belum terkomputerisasi, belum adanya pematenan produk, minimnya pengetahuan tentang keuangan, kurang mengetahui regulasi usaha terbaru, kurang aktif dalam program pemerintah, dan kurang siap dalam perubahan kondisi ekonomi seperti pasar bebas. Namun hasil penelitian tersebut juga menemukan beberapa peluang yang didapatkan dari UMKM antara lain pasar yang luas, kemudahan legalitas produk, pelatihan peningkatan keahlian dan pembinaan program kemitraan usaha dari pemerintah daerah, selain itu semakin maraknya tempat dan kegiatan dapat membantu pengusaha dalam memasarkan usaha seperti adanya food festival. ${ }^{2}$

Analisis dalam penelitian tersebut menyimpulkan bahwa strategi yang tepat untuk mengembangkan UMKM di Kota Tegal adalah melalui pemanfaatan peluang yang ada dengan melakukan ekspansi pasar, memperbesar pertumbuhan produksi dan mengupayakan kemajuan teknologi secara maksimal. Strategi tersebut dapat dilakukan salah satunya adalah dengan melakukan riset pasar untuk mengetahui pendapat dan kebutuhan konsumen terkait produk yang ditawarkan oleh UMKM di Kota Tegal. Berdasarkan latar belakang tersebut maka perlu dilakukan kegiatan pengabdian masyarakat untuk membantu para UMKM di Kota Tegal dalam melakukan riset pasar dari produknya masing-masing agar tercapai tujuan utama yaitu meningkatkan pendapatan usahanya.

Diharapkan dengan adanya Kegiatan Pengabdian kepada Masyarakat ini para UMKM di Kota Tegal dapat melakukan riset pasar secara mandiri dan berkala. Hasil riset pasar tersebut dapat dimanfaatkan oleh para UMKM di Kota Tegal untuk menganalisis produknya dan dapat dilakukan perbaikan dan inovasi yang sesuai dengan permintaan dan selera konsumen. Dengan dilakukannya perbaikan dan inovasi produk tersebut nantinya dapat meningkatkan pendapat usaha para UMKM di Kota Tegal.

\section{Target dan Luaran}

Sasaran pengabdian masyarakat adalah para UMKM di Kota Tegal. Tim pengabdian masyarakat bekerja sama dengan RKB BNI atau Rumah Kreatif BUMN BNI Kota Tegal dalam menjaring peserta dalam kegiatan pengabdian ini. Peserta kegiatan pengabdian ini merupakan UMKM anggota RKB BNI Kota Tegal. Dengan kerjasama tersebut harapannya kegiatan ini tepat 
sasaran dan dapat memiliki manfaat yang maksimal bagi UMKM Kota Tegal khususnya dalam melakukan riset pasar secara mandiri.

\section{Metodologi}

Metode dalam pelaksanaan kegiatan pengabdian kepada masyarakat ini $^{3}$ adalah sebagai berikut:

\subsection{Pemetaan (mapping)}

Langkah awal, tim pengabdian melakukan koordinasi dan kerjasama dengan RKB BNI Kota Tegal, tahap selanjutnya adalah publikasi kegiatan untuk menjaring peserta. Dalam kegiatan publikasi ini, tim pengabdian dibantu anggota RKB BNI Kota Tegal dengan cara menyebarkan pamflet dan informasi melalui grup RKB. Peserta dibatasi sebanyak 10 orang agar kegiatan ini dapat berjalan lebih maksimal.

\subsection{Metode Survei}

Setelah dilakukan pemetaan, selanjutnya tim pengabdian melakukan survei melalui pengisian Google Form yang dibagikan sebelum kegiatan dimulai untuk mengetahui peserta yang mendaftar. Dalam form tersebut, peserta diminta mengisi beberapa pertanyaan yang nantinya digunakan oleh tim pengabdian untuk mengetahui kondisi para UMKM seperti nama, jenis kelamin, usia, alamat, nomer hp, nama usaha, jenis usaha dan pengalaman riset pasar yang telah dilakukan sebelumnya.

\subsection{Perumusan Masalah dan Solusi}

Dari hasil survei yang telah dilakukan melalui penyebaran Google form kepada peserta UMKM, selanjutnya tim pengabdian mencoba merumuskan masalah mengenai kondisi para peserta dalam riset pasar. Beberapa peserta yang telah melakukan riset pasar sebelumnya dihubungi dan dimintai informasi mengenai pengalaman riset pasar yang telah mereka lakukan. Untuk kemudian dapat dirumuskan masalah agar dapat ditentukan solusi yang tepat.

\subsection{Studi Literatur sebagai metode Penyelesaian Masalah}

Tim Pengabdian selanjutnya melakukan studi literatur mengenai analisis riset pasar yang dapat digunakan untuk mengembangkan usaha peserta UMKM di Kota Tegal dengan mengacu pada rumusan masalah yang sudah dibuat sebelumnya. Studi literatur dilakukan agar materi yang disampaikan dapat disesuaikan dengan kondisi dan pemahaman para peserta UMKM dengan memperhatikan pengalaman riset pasar yang telah dilakukan oleh beberapa peserta sebelumnya.

\subsection{Tahap Pelaksanaan}

Pelaksanaan Pengabdian Kepada Masyarakat ini dilakukan dengan menggunakan metode ceramah dan diskusi. Adapun sistematika pelaksanaan kegiatan pengabdian adalah sebagai berikut:

\subsubsection{Metode Ceramah}

Materi yang telah disiapkan oleh tim disampaikan kepada para peserta UMKM Kota Tegal menggunakan metode ceramah.

\subsubsection{Metode Diskusi}

Setalah dilakukan penyampaian materi, selanjutnya adalah sesi diskusi yang bertujuan untuk memberi kesempatan kepada para peserta UMKM Kota Tegal untuk bertanya mengenai materi yang telah disampaikan. Selain itu, sesi diskusi juga memberikan kesempatan kepada peserta untuk berbagi informasi dan pengalaman mereka mengenai riset pasar yang telah dilakukan sebelumnya.

\section{Pembahasan}

Riset pasar merupakan salah satu hal yang penting dalam pengembangan suatu usaha. Akan tetapi beberapa pengusaha kurang menguasai metode analisis riset pasar yang baik. Sehingga hasil yang didapatkan dari riset pasar yang telah dilakukan, kurang dapat mewakili kondisi usaha yang dimiliki. Selain itu, beberapa pengusaha bahkan kurang memiliki minat dalam melakukan riset pasar usahanya.

Berdasarkan permasalahan usaha dari sebagian UMKM Kota Tegal yang dianalisis oleh tim pengabdian melalui survei sebelumnya, menghasilkan rumusan strategi yang dapat dilakukan untuk menambah pengetahuan dan pemahaman riset pasar yang baik. Strategi 
tersebut tertuang pada kegiatan Pengabdian Kepada Masyarakat ini. Dari hasil rekap data peserta, didapatkan informasi bahwa dari 10 peserta, 3 peserta diantaranya pernah melakukan riset pasar sebelumnya yaitu atas nama Ibu Murtiningsih, Bapak Ari dan Ibu Marchinia. Ketiga peserta tersebut kemudian dihubungi untuk konfirmasi ulang dan ditawarkan untuk menyampaikan pengalamannya pada pelaksanaan kegiatan PKM nantinya.

Dalam pelaksanaan pengabdian, penyampaian materi yang telah dirumuskan melalui survei kebutuhan para UMKM Kota Tegal diberikan oleh tim pengabdian kepada 10 orang UMKM Kota Tegal sebagai sampel awal. Pelaksanaan kegiatan PKM diawali dengan pengenalan pengetahuan dan pemahaman mengenai Riset Pasar, Tahapan Riset Pasar, dan Metode Analsisi Riset Pasar.

Berdasarkan hasil pengamatan langsung dan diskusi selama kegiatan berlangsung, kegiatan pengabdian masyarakat ini memberikan hasil sebagai berikut:

a. Meningkatnya pengetahuan dan pemahaman UMKM Kota Tegal mengenai Riset Pasar.

b. Meningkatnya pengetahuan dan pemahaman UMKM Kota Tegal mengenai tahapan dalam Riset Pasar.

c. Meningkatnya pengetahuan dan pemahaman UMKM Kota Tegal mengenai metode analisis Riset Pasar (Kualitatif dan Kuantitatif)

d. Meningkatnya minta UMKM Kota Tegal dalam melakukan Riset Pasar usahanya dengan baik dan terarah.

Kegiatan PKM ini merupakan tahap awal dilakukannya pendampingan dalam analisis riset pasar sebagai upaya peningkatan usaha UMKM Kota Tegal. Untuk tahap selanjutnya, akan dilakukan pendampingan dalam perumusan tahapan dilakukannya riset pasar pada masingmasing UMKM Kota Tegal (tidak berkelompok).

\section{Kesimpulan}

Pelaksanaan pengabdian masyarakat ini telah berjalan sesuai dengan jadwal yang telah direncanakan. Dari kegiatan pengabdian masyarakat yang telah dilaksanakan dapat disimpulkan bahwa: a. Tim pengabdian masyarakat Prodi DIII Akuntansi telah berhasil melaksanakan kegiatan pengabdian dengan tema : "Upaya Peningkatan Pendapatan Usaha Melalui Analisis Riset Pasar Pada UMKM di Kota Tegal".

b. Kegiatan pengabdian masyarakat yang dilakukan oleh Prodi D III Akuntansi dapat dikatakan berhasil dan mendapatkan tanggapan positif peserta kegiatan yang merupakan UMKM Kota Tegal.

c. Pengetahuan, pemahaman dan ketrampilan peserta mengenai riset pasar meningkat.

d. Terjalin kemitraan antara Politeknik Harapan Bersama dengan UMKM Kota Tegal khususnya UMKM yang merupakan anggota RKB BNI.

\section{Ucapan Terima Kasih}

Ucapan terima kasih kami sampaikan kepada Politeknik Harapan Bersama khususnya Prodi DIII Akuntansi yang telah mendukung sepenuhnya dalam pelaksanaan kegiatan pengabdian ini. Terima Kasih juga kami sampaikan kepada pihak RKB BNI Kota Tegal yang berkenan melakukan kerjasama dengan kami dalam menghimpun peserta kegiatan pengabdian ini. Serta terima kasih kami ucapkan kepada seluruh peserta kegiatan pengabdian masyarakat yaitu UMKM Kota Tegal atas kesediaannya dalam mengikuti rangkaian kegiatan pengabdian ini.

\section{Daftar Pustaka}

[1] Aditama., 2014. Riset Pasar Produk Keripik Tempe Sagu. Skripsi, Program Studi Teknik Industri. Fakultas Industri, Universitas Atmajaya Yogyakarta.

[2] Karunia, Anita, dkk., 2019. Kajian Strategi Pengembangan Usaha Mikro, Kecil dan Menengah (UMKM) di Kota Tegal.

[3] Sugiyono, 2014. Statistika untuk Penelitian. Alfabeta, Bandung 